\title{
Morphological Diversity Assessment of Nigeria Sorghum Landraces for Utilization in Hybrid Parent Development
}

\author{
Angarawai I. Ignatius ${ }^{1, *}$, Willmar Leiser ${ }^{2}$, Baloua Nebie ${ }^{3}$, Yeye Y. Mary ${ }^{4}$, Aba A. Daniel ${ }^{4}$, \\ Abubakar Lawali ${ }^{5}$, Ajeigbe H. A ${ }^{1}$, Jonah Jerome ${ }^{1}$ \\ ${ }^{1}$ International Crop Research Institute for Semi-Arid Tropics Kano, Nigeria \\ ${ }^{2}$ University of Hohenheim, Germany \\ ${ }^{3}$ International Crop Research Institute for Semi-Arid Tropics Bamako, Mali \\ ${ }^{4}$ Institute for Agricultural Research, Ahmadu Bello University, Zaria \\ ${ }^{5}$ Usman Dan-Fodio University, Nigeria
}

Received October 22, 2018; Revised September 16, 2019; Accepted September 23, 2019

Copyright $\bigcirc 2019$ by authors, all rights reserved. Authors agree that this article remains permanently open access under the terms of the Creative Commons Attribution License 4.0 International License

\begin{abstract}
Challenge in hybrid sorghum development for the Nigerian environment remains the identification of suitable seed parents, constrained most particularly by non-appropriate indigenous sources of stable male-sterility maintenance on the female parents. To achieve this goal, defined "functional" heterotic parental-pools is required to create new and diverse hybrid parents for sustainable hybrid development. To explore availability of male-sterility inducing cytoplasm, an exploratory landrace Sorghum collection across some states of Nigeria 2014 and 2015 were carried out and evaluated for target hybrid parent traits. 388 testcrosses generated from 40 randomly selected landraces collections using 2 male sterile lines (ICS38A and ICS24005A), were evaluated for sterility maintainer to identify lines that are suitable for conversion to male sterile lines and restorers. Preliminary characterization during 2014 cropping season evaluation showed that most of the sorghum landraces grown in the Sudan Savannah are white or yellow grain with compact elliptic panicle forms (caudatum type) accounting for $46 \%$ as compared to those in Guinea Savannah cultivating white or red grain with loose dropping panicle forms (guinea type). Result from the genomic analysis revealed wide genetic diversity with 5 major distinct clusters at 0.2 Euclidian distances. The genetic materials used as parents in the testcrosses showed high potential of genetic male sterility maintainers and were diverse, where 3 of the landrace parents were mapped to cluster 1,13 to cluster 2, 1 to cluster 3 and 3 to cluster 5 . Given that the collection areas are diverse with heterogeneous agro-ecologies, the landraces observed could be used as important sources of novel alleles for developing hybrid parents.
\end{abstract}

Keywords Sorghum, Hybrid, Male Sterility, Landraces, Clusters

\section{Introduction}

Sorghum [Sorghum bicolor (L.) Moench] is the fifth most important cereal crop in the world, but first important cereal in Nigeria. It is the most extensively traditionally grown cereal in the savannas of Nigeria extending from the Southern Guinea to Sahelien Savannah agro-ecologies of Nigeria, primarily because of its adaptation to drought. These agro-ecological zones cover at least fifteen States namely Adamawa, Bauchi, Borno, Gombe, Jigawa, Kaduna, Kano, Katsina, Kebbi, Nasarawa, Niger, Benue, Kogi, Kwara, Plateau, Sokoto, Taraba, Yobe and Zamfara States. The country produced 8.5 million tons in 2008, 9.3 million tons in 2009 and 10.0 million tons in 2010 with a projection of being the largest sorghum grain producer in the world [1] by 2020. Sorghum was cultivated on about 10.845 million hectares in 2014 [2], representing about $50 \%$ of the total area under cereal crop production and about $13 \%$ of the total arable land in the country.

Millions of rural resource limited smallholder farmers in the dry savannas of Nigeria consume sorghum in their daily diets as staple food where flour is locally processed into 'towo' and non-alcoholic beverage like 'kunun-zaki'. In addition to this popularity of sorghum use in traditional dishes, there is now a gradual increase in demand for pre-processed sorghum foods for convenience and in the malting industry. The industrial demand for sorghum is growing with several flour mills in the country using it in addition to wheat to produce composite flour as well as high energy foods. Based on the increasing demand by malting industries for beverages the expected increase for use of sorghum will rise by about $30 \%$ in 
coming years.

Although sorghum is an indigenous crop and exceptionally adapted to the region, the yields are generally less than 1.5t/ha [3]. Important factors among others that contribute to these low yields includes; low inputs, poor soil fertility and the non-availability of improved varieties or hybrids with significant yield superiority over farmers' landrace varieties.

Guinea-race based sorghum hybrids developed by joint ICRISAT-IER Mali breeding activities from 2000 to 2008 showed average yield advantages of $35 \%$ over a large number of on-farm tests, thus providing proof of concept of photoperiod sensitive hybrids for WCA [4]. However, its suitable only for a single maturity band $(100 \mathrm{~km}$ north-south latitude) for the Guinea-race zone of Senegal, Mali and Burkina Faso, which do not meet the adaptation or grain quality requirements especially for the drier zones of Nigeria growing the durra and caudatum types.

The potential of hybrid sorghum to provide yield advantages under drought stressed conditions in semi-arid areas of Kenya was shown by Haussmann et al. [5, 6]. Even higher yield advantages were shown with Nigerian germplasm in preliminary on-station testing [7], although the parental materials have since been lost. It is in this context that the need to collect germplasm was conceived for the identification of suitable seed parents to develop hybrid sorghum for the Nigerian environment, constrained most particularly by non-appropriate indigenous sources of stable male-sterility maintenance on the female parents.

Using the modern molecular tools, plant breeders can now explore several fertility restoration genes for different cytoplasmic male sterility (CMS) systems mapped in sorghum $[8,9,10]$, an opportunity to develop new and improved cultivars with farmer and industry desirable or preferred traits like yield potential, bold grain seed, and pest and disease resistance [11], currently used in Mali in the A1-CMS system. The major gene for pollen restoration in the A1-system is the $R f 1$ gene, a pentatricopeptide repeat protein. Mapping new loci would be necessary if these loci are not effective for characterizing restoration capability of WCA germplasm. Genetic markers for fertility restoration would speed up the A and R line development and thus widen the genetic basis for producing more suitable hybrids. Assessment of the target morphological traits of Nigeria landrace sorghum lines is aimed at identifying and defining "functional" heterotic parental-pools for utilization in hybrid parent development and thus increase the productivity of sorghum to meet the increasing rural and industrial demand.

\section{Materials and Methods}

\subsection{Germplasm collection Testcross Development}

International crop Research Institute for Semi-Arid
Tropics (ICRISAT), Nigeria Kano Office, in collaboration with National Partners \{Institute for Agricultural Research, Ahmadu Bello University (IAR/ABU) Zaria, Usman Dan Fodio University Sokoto (UDUS), Federal University Wukari (FUW) and National Centre for Genetic Resources and Biotechnology (NACGRAB), facilitated the collection of landrace sorghum across some Northern states (Bauchi, Borno, Gombe, Jigawa, Kaduna, Kano, Katsina, Kebbi, Kogi, Kwara, Plateau, Yobe and Zamfara) of Nigeria in 2014 and 2015. Collections were done at 50 to $100 \mathrm{Km}$ intervals within the drier Northern Guinea, Sudanian and Sahelien agro-ecology were bulk of the sorghum are cultivated. For each entry, seeds were obtained from at least 50-100 random panicles, against which the farmers name, village, grain color, panicle forms and location GPS were recorded.

During 2015 cropping season, using 40 randomly selected landraces from the collections on 2 male sterile lines (ICS38A and ICS24005A), 388 testcrosses were generated at Samaru Zaria.

\subsection{Germplasm and Testcross Evaluation for Male Sterility Maintainer}

Three hundred and Forty-seven (347) diverse Landrace sorghum comprising of 70 lines from 2014 collections, 160 lines from 2015 collections, 59 lines sourced from Diversity Trust, 44 diverse lines from ICRISAT-Mali and 14 common checks were evaluated at Zaria on 1 row plot spaced $75 \mathrm{~cm}$ inter-row and intra -row spacing of $30 \mathrm{~cm}$ between hills layout in Alpha Lattice Design with 2 replications. Thinning was carried out 2 weeks after sowing (WAS) with NPK fertilizer 15:15:15 as micro-dose at $6 \mathrm{~g} / \mathrm{hill}$. Urea $(46 \% \mathrm{~N})$ was split applied at 6 and 10 weeks after sowing to ensure availability of nutrients up-to grain filling. $1^{\text {st }}$ and $2^{\text {nd }}$ weeding was manually done at 2 and 8 WAS respectively. Crop parameters, the key traits for hybrid parents, that were recorded includes; plant height; measured on 5 random plants using graduated $5 \mathrm{~m}$ height ruler, days to $50 \%$ flowering; from days of planting to when $50 \%$ of the plants per plot reached anthesis, panicle type; were scored according to sorghum descriptor, panicle length; of 5 random panicles and grain color based on grain color chart of IBPGR and ICRISAT [12].

During 2017 cropping season, the testcrosses generated along with their parents were evaluated on a 2-row plot of $5 \mathrm{~m}$ long spaced $0.75 \mathrm{~m}$ apart, using head to head cover at heading before anthesis to score for sterility maintainer at Bagauda -Kano Nigeria.

\subsection{Molecular Marker Screening}

Discarding the 59 lines sourced from Diversity Trust based on similarity with 2014 and 2015 collections, the 288 landraces comprising of 70 lines from 2014 collections, 160 lines from 2015 collections, 44 diverse lines from 
ICRISAT-Mali and 14 common checks, were genotyped using 20 SSR markers at the University of Hohenheim Germany to understand the diversity at genomic level and further grouping of the landraces into heterotic pools. The Euclidean dissimilarity matrix was used to cluster genotypes using the UPGMA algorithm to develop the dendrogram.

\section{Results and Discussion}

\subsection{Morphological Characters}

Preliminary characterization showed that there exists significant variability within the collected sorghum landraces as presented on Table 1. Days to $50 \%$ flowering ranged from 71-121 days and plant height ranged from $130-512.5 \mathrm{~cm}$. Panicle shape and grain colour varied significantly where majority of the those grown in the sahelien agro-ecology were white (Farafara) while those from sudanian agro-ecology were yellow grain (Kaura) with compact elliptic panicle forms. These accounts for $46 \%$ of the genotypes mostly early caudatum types. Few guinea types are cultivated in the Northern Guinea Savannah mostly red grain (5\%) with loose dropping panicle forms (guinea type) and generally late (Figures 1 and 2). 100 seed weight and Grain yield per plot were observed to be statistically significant ranging from $1-5 \mathrm{~g} / 100 \mathrm{grains}$ and $0-1400 \mathrm{~g} / \mathrm{plot}$ respectively, indicating an opportunity for selection in hybrid parent development. This variability in sorghum was earlier observed by Belum et al., [13] while charactering some ICRISAT Mini-core collections, which also the basis for selection. This could be attributed to the fact that those in the Sudan which have relative low rains requires early maturing varieties compared to those in the Guinea with high rains. Either the Farafara or Kaura types grown in the Sudan ecology with less insect pest is characterized with compact elliptic panicle forms (caudatum type) compared to those in Guinea Savannah cultivating white or red grain with loose dropping panicle forms (guinea type) thus avoiding grain mold and insect damage. This implies that Sorghum hybrid parent development should at present target, high yielding white or yellow grains with compact elliptic panicle forms, medium height (2m) and medium maturity (100 days), for sustainable hybrid sorghum production. Learning from Belum et al. [13], sorghum germplasm characterization should be where the source is better adapted or another location where information from the collection site is utilized.

Table 1. Means, range, estimated components of variance for genotypic effects V(G), and standard error for various sorghum hybrid parent target traits

\begin{tabular}{|c|c|c|c|c|}
\hline Trait & Mean & Range & V (G) & $\mathrm{SE} \pm$ \\
\hline Days to $50 \%$ flowering (days) & 93 & 71- 121 & $120.1527 * *$ & 10.8162 \\
\hline Plant height (cm) & 268.74 & $130-512.5$ & 67.66868* & 0.5510 \\
\hline Panicle Shape & - & $1-6$ & $18.453781^{* *}$ & 1.468104 \\
\hline Gain colour & - & $1-4$ & $0.8101508^{* *}$ & 0.0644521 \\
\hline 100 grain weight (g) & 2.96 & $1-5$ & $0.3859491^{*}$ & 0.12764 \\
\hline Grain yield/plot (g) & 830.71 & $0-1400$ & _720500.8** & 61469.227 \\
\hline
\end{tabular}

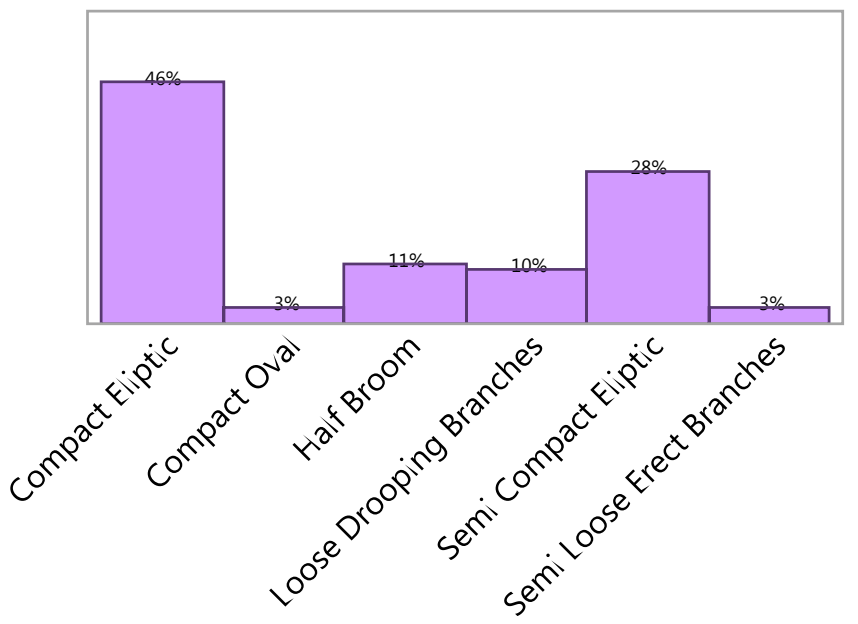

Figure 1. Variability for panicle shapes 


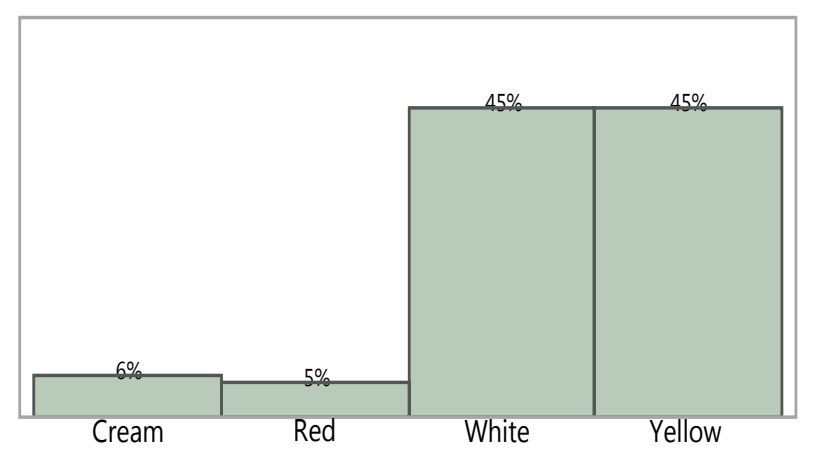

Figure 2. Variability for grain colour types

\subsection{SSR Marker Screening}

Based on sources of germplasm, 2014 collections were assigned blue, 2015 collections were assigned red while materials from Mali were assigned black colours. Result of screening using the 20 SSR markers revealed wide genetic diversity among the sorghum genotypes studied. The resulting dendrogram revealed 5 major distinct clusters at 0.2 Euclidian distances (Figure 3). Germplasm collection of 2014 and 2015 were distributed across the 5 cluster, indicating genetic dissimilarity, high chance for selection among the Nigerian landrace collections. Those from Mali, which were basically the guinea types tend to cluster at Cluster together (Figure 3 sub cluster $3 b$ ), indicating genetic similarity, belonging to one heterotic pool and thus little chance for selection compared to the diversity experienced among Nigerian landrace collections.

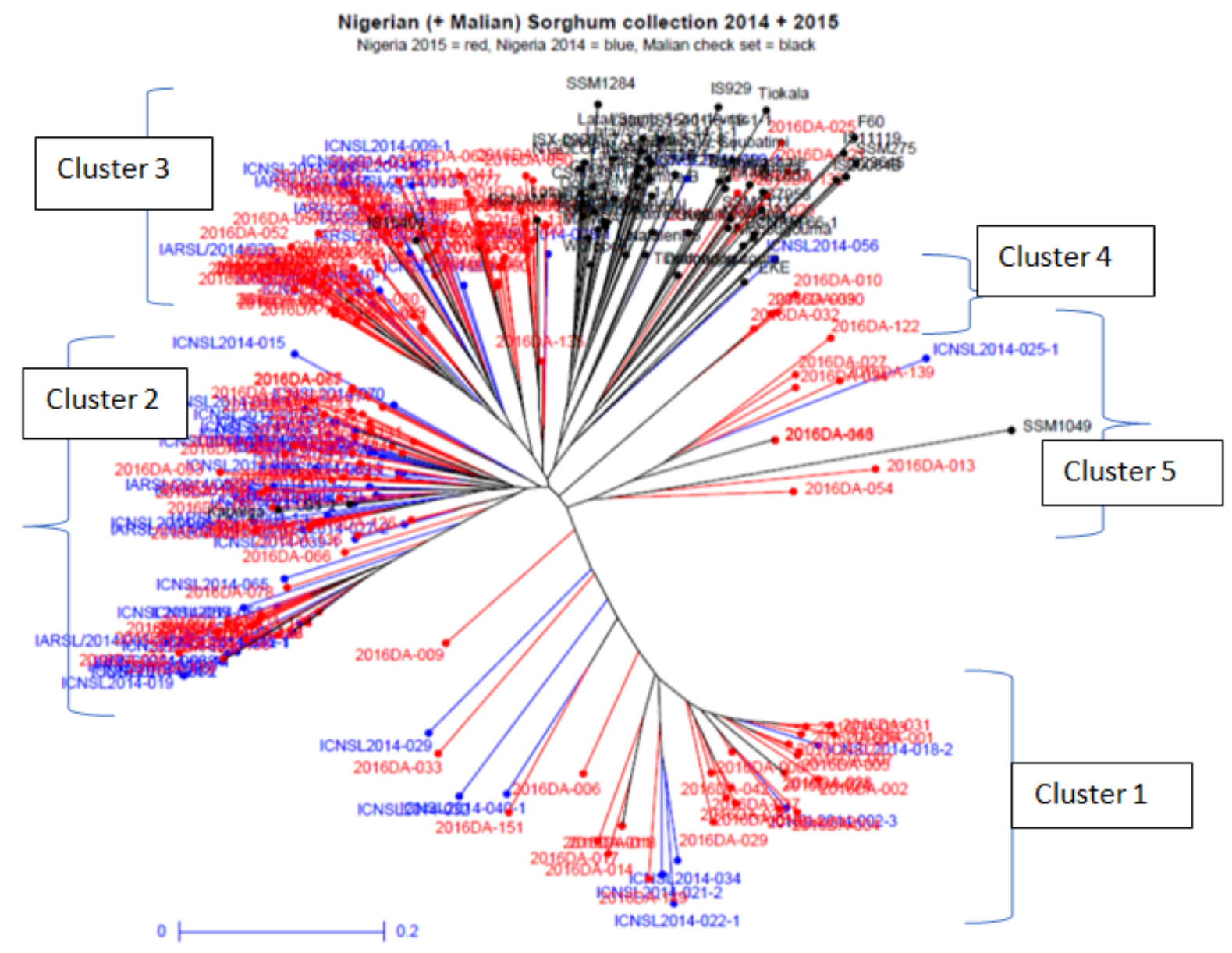

Figure 3. Dendrogram showing 5 major distinct clusters at 0.2 Euclidian distances 


\subsection{Male Sterility Maintainer Identification}

Result of 2017 screening for male sterility maintainer, presented in Table 2, showed that 23 progenies from among the 388 testcross progenies were identified with sterile heads during, indices of sterility maintainer sources. Landrace parents of the testcross progenies were also found to be diverse in plant height (PLH), panicle shape, panicle length and Days to 50\% flowering (DF) as shown in Figure 4 clustering into 5 distinct heterotic groups. Three of the landrace parents were mapped to cluster 1, 13 to cluster 2, 1 to cluster 3 and 3 to cluster 5 most of which were traced to be materials collected from drier Northern Nigeria axis of Sokoto, Katsina, Jigawa and Zamfara states (Figure 5). Materials from these regions considering their distribution across the different cluster showed high variability, suggesting high potential for sterility maintainers and can be explored for hybrid parent development.

Table 2. List of testcross progenies with Nigeria landrace parent identified as male sterility maintainers at Bagauda Nigeria during 2017 cropping season evaluation

\begin{tabular}{|c|c|c|c|c|c|c|c|}
\hline Serial Number & Entry Code & Testcross pedigree & Landrace Code & Cluster group & Agro-ecology & State & Local Govt. Area \\
\hline 1 & 2016DA-003 & 24005A X Mai masaba-9 & CAPARLKSG20150308 & 2 & Sudan savannah & Jigawa & Yanyanga \\
\hline 2 & 2016DA-005 & 24005A X Mace da kunya-1 & CAPARLGSG2015-0007 & 1 & Sudan & Sokoto & KwAREA \\
\hline 3 & 2016DA-007 & 24005A X Jardawa Baguba-2 & CAPARLGSG2015-0011 & 1 & Sudan & Sokoto & Silami \\
\hline 4 & 2016DA-018 & 24005A X Rosoba-1 & CAPARLGSG2015-0031 & 1 & Sudan & Sokoto & Gada \\
\hline 5 & 2016DA-026 & 24005A X Keki jinin shanu-1 & CAPARLGSG2015-0057 & 3 & Sudan & Sokoto & Illela \\
\hline 6 & 2016DA-040 & 24005A X Sambalma-1 & CAPARLGSG20150085 & 2 & & Zamfara & Bakure \\
\hline 7 & 2016DA-041 & 38A X Gagaran & CAPARLGSG20150092 & 2 & & Zamfara & Maradun \\
\hline 8 & 2016DA-043 & 24005A X Yar falgori-1 & CAPARLGSG20150095 & - & & Zamfara & Zurmi \\
\hline 9 & 2016DA-054 & 38A X Gagarauja-2 & CAPARLGSG20150114-2 & 3 & & Zamfara & Baku yam \\
\hline 10 & 2016DA-056 & 24005A X Dawa-2 & CAPARLGSG20150116-3 & - & & Zamfara & Bukyum \\
\hline 11 & 2016DA-120 & 24005A X Jardawa -2 & CAPARLKSG20150278 & 2 & Sahel savanna & Katsina & Daga \\
\hline 12 & 2016DA-122 & 24005A X Yar kusada-1 & CAPARLKSG20150280 & 3 & Sahel savanna & Katsina & Ruma \\
\hline 13 & 2016DA-123 & 24005A X Yar mallamawa-4 & CAPARLKSG20150281 & 2 & Sahel savanna & Katsina & Ruma \\
\hline 14 & 2016DA-125 & 24005A X Gara gajiya-3 & CAPARLKSG20150284 & 2 & Sahel savanna & Katsina & Kasai \\
\hline 15 & 2016DA-125 & 24005A X Gara gajiya-4 & CAPARLKSG20150284 & 2 & Sahel savanna & Katsina & Kasai \\
\hline 16 & 2016DA-126 & 24005A X Badari -6 & CAPARLKSG20150285 & 2 & Sahel savanna & Katsina & Kasai \\
\hline 17 & 2016DA-133 & 38A X Kaura -19 & CAPARLKSG20150292 & 2 & Sudan & Katsina & Kura \\
\hline 18 & 2016DA-134 & 38A X Kakurundu -5 & CAPARLKSG20150293 & 3 & Sudan & Katsina & Kura \\
\hline 19 & 2016DA-139 & 38A X Jar dawa lara-2 & CAPARLKSG20150298 & 2 & Sudan savannah & Jigawa & Chaichai \\
\hline 20 & 2016DA-142 & 24005A X Wild Sorghum bicolor L. Moench-3 & CAPARLASG2015002 & 2 & Sahel-Savanna & Yobe & Fika \\
\hline 21 & 2016DA-148 & 24005A X Kwandala-4 & CAPARLKSG20150311 & 2 & Sudan savannah & Jigawa & Yanyanga \\
\hline 22 & 2016DA-148 & 24005A X Kwandala-7 & CAPARLKSG20150312 & 2 & Sudan savannah & Jigawa & Yanyanga \\
\hline 23 & 2016DA-159 & 24005A X Zauna-Inuwa-6 & check & 2 & & & \\
\hline
\end{tabular}




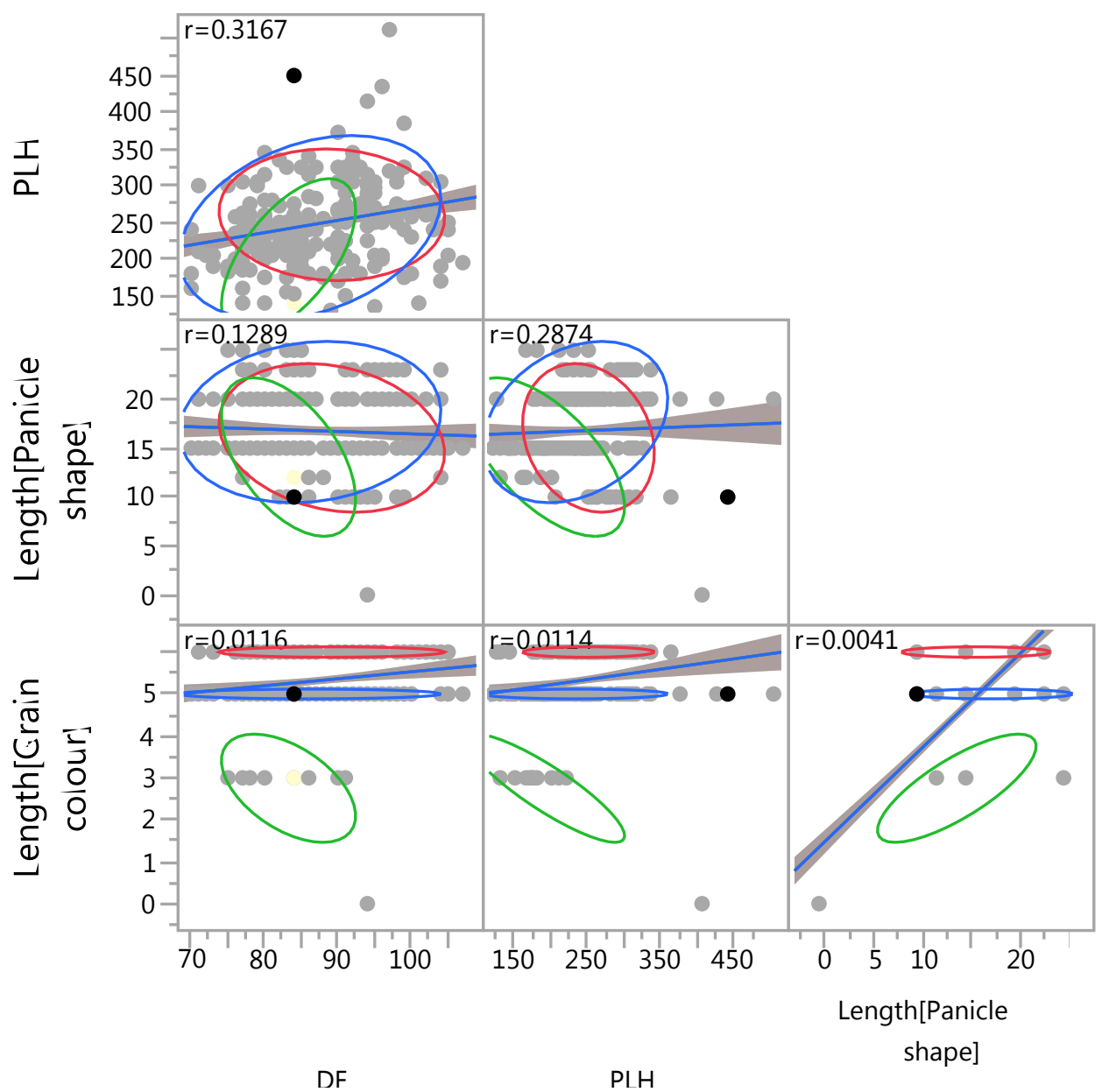

Figure 4. Scatterplot Matrix

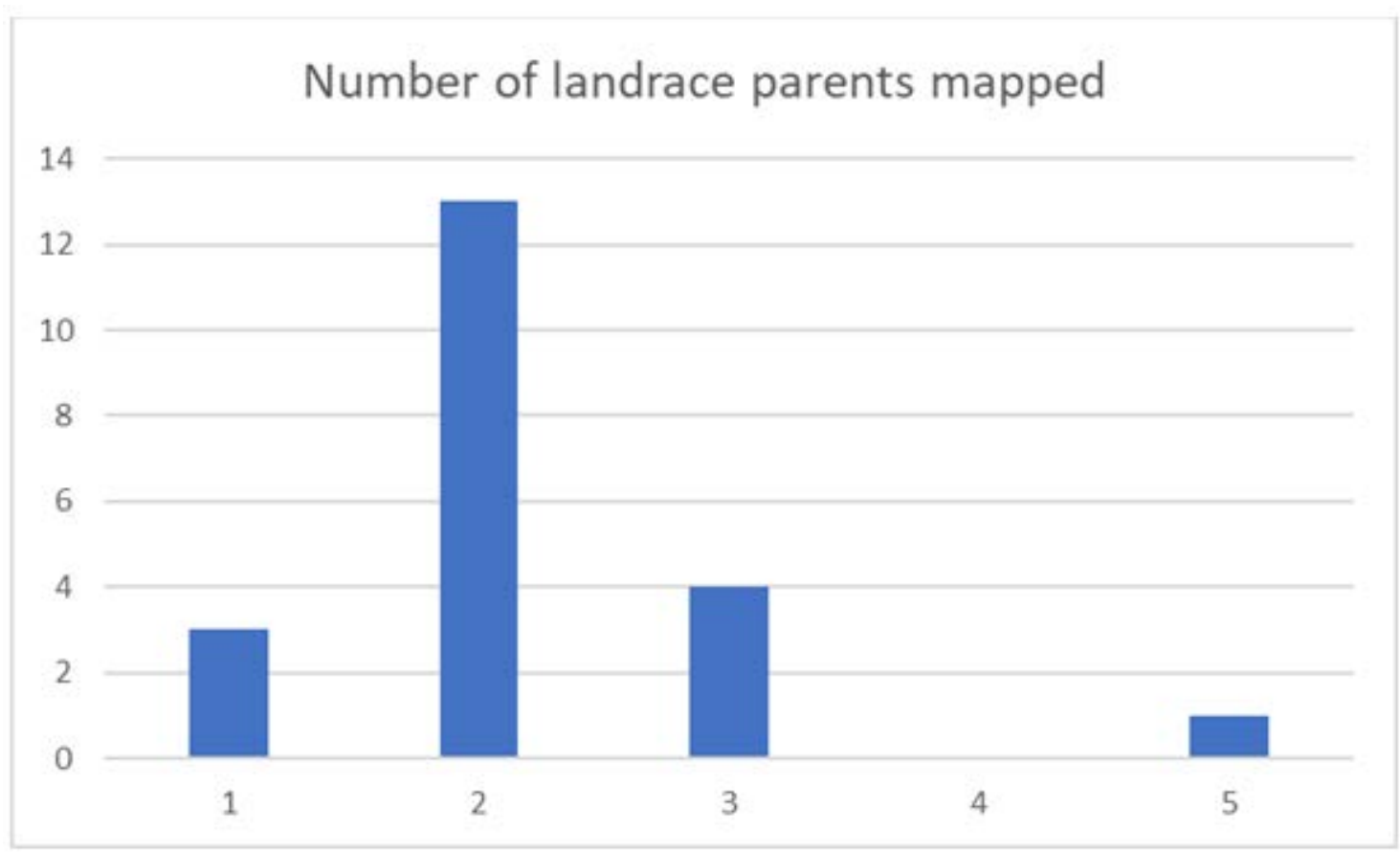

Figure 5. Number of landrace parent with sterile progenies mapped to different clusters 


\section{Summary and Recommendation}

Result from this study based on both morphological and genomic data analysis revealed wide genetic diversity. Though broadly classified into two broad generic popular Farafara (white grain) and Kaura (yellow grain) types, there exists significant variability for grain colour, panicle forms, plant height and days to flowering among the materials, suggesting high selection probability for crop improvement. SSR marker studies revealed wide genetic diversity among the sorghum genotypes clustering into 5 major distinct clusters at 0.2 Euclidian distances thus creating high opportunity and chances for selection among the heterotic groups with high potential of genetic male sterility maintainers.

Given that the collection areas were diverse with heterogeneous agro-ecologies associated with high genetic, the landraces observed can serve as important potential sources of novel alleles for developing hybrid parents.

Sorghum improvement will be to concentrate on the utilization of desirable traits that may aid in evolving superior improved lines aiming to surpass the present productivity plateau combined with better drought, disease and pest resistance and improved grain quality. Sorghum hybrid parent development should at present therefore target, high yielding white or yellow grains with compact elliptic panicle forms, medium height $(2 \mathrm{~m})$ and medium maturity (100 days). However, DNA marker techniques to identify diverse segments of the chromosomes controlling inheritance of fertility restoration genes for different cytoplasmic male sterility will become necessary to facilitate germplasm utilization programs.

\section{REFERENCES}

[1] Agricultural Transformation Agenda (ATA) 2011: We Will Grow Nigeria’s Agricultural Sector. Federal Ministry of Agriculture and Rural Development Abuja, Nigeria. 9th September, 2011

[2] National Agricultural Extension and Research Liaison Services (2014). A Report on Adopted Village Concept for Agricultural Technology Transfer: NAERLS Experience (1)32-40

[3] FAO. 2014. FAOSTAT. Available http://faostat.fao.org

[4] Rattunde, H.F.W., E. Weltzien, B. Diallo, A.G. Diallo, M. Sidibe, A.O. Touré, A. Rathore, R.R. Das, W.L. Leiser, and Al. Touré. 2013. Yield of photoperiod-sensitive sorghum hybrids based on Guinea-race germplasm under farmers' field conditions in Mali. Crop Science 53 (November-December): 1-8.

[5] Haussmann, B.I.G., A.B. Obilana, A. Blum, P.O. Ayiecho, W. Schipprack, and H.H. Geiger. 1998. Hybrid performance of sorghum and its relationship to morphological and physiological traits under variable drought stress in Kenya. Plant Breeding 117: 223-229.
[6] Haussmann, B.I.G., A.B. Obilana, A. Blum, P.O. Ayiecho, W. Schipprack, and H.H. Geiger. 2000. Yield and yield stability of four population types of grain sorghum in a semi-arid area of Kenya. Crop Science 40: 319-329.

[7] Andrews, D.J. 1975. Sorghum grain hybrids in Nigeria. Experimental Agriculture 11: 119-127.

[8] Klein, R.R., P.E. Klein, J.E. Mullet, P. Minx, W.L. Rooney, and K.F. Schertz. 2005. Fertility restorer locus Rf1 of sorghum (Sorghum bicolor L.) encodes a pentatricopeptide repeat protein not present in the colinear region of rice chromosome 12. Theoretical and Applied Genetics 111(6): 994-1012.

[9] Jordan, D.R., E.S. Mace, R.G. Henzell, P.E. Klein, and R.R. Klein. 2010. Molecular mapping and candidate gene identification of the Rf2 gene for pollen fertility restoration in sorghum [Sorghum bicolor (L.) Moench]. Theoretical and Applied Genetics 120(7): 1279-1287.

[10] Jordan, D.R., R.R. Klein, K.G. Sakrewski, R.G. Henzell, P.E. Klein, and E.S. Mace. 2011. Mapping and characterization of Rf 5: a new gene conditioning pollen fertility restoration in A1 and A2 cytoplasm in sorghum (Sorghum bicolor (L.) Moench). Theoretical and Applied Genetics 123(3): 383-396.

[11] Govindaraj, M., M. Vetriventhan, and M. Srinivasan (2015). Importance of Genetic Diversity Assessment in Crop Plants and Its Recent Advances: An Overview of Its Analytical Perspectives. Genetics Research International. Volume 2015, Article ID 431487, 14 pages http://dx.doi.org/10.115 5/2015/431487

[12] IBPGR and ICRISAT. 1993. Descriptors for sorghum [Sorghum bicolor (L.) Moench].International Board for Plant Genetic Resources, Rome, Italy; International Crops Research Institute for the Semi-Arid Tropics, Patancheru, India.

[13] Belum VS Reddy, A. Ashok Kumar, P Sanjana Reddy and M Elangovan (2011). Sorghum germplasm: diversity and utilization. https://core.ac.uk/download/pdf/12106667.pdf 